geration temporarily of the symptoms and signs of the local infection. The reaction at the site of inoculation in such cases may pursue a course similar to vaccination.

Sueh consequences depend on the altered reaction of the organism toward the particular bacterial product. The extent of the reaction will depend on this factor, the quantity of vaccine employed and the method of administration. This holds true not only for tuberculin, but for all vaccines. I have observed pronounced clinical and stick (inoculation site) reactions, following the use of staphylococcus, streptococeus; gronococcus, ete, vaccines. The stick reaction (the tender nowille under the skin at the point of injection) is the more (4)mmon and has diagnostic value. The injection of a very large dose for the patient of any vaccine, corresponding to the organism or organisms causing the disease, may give rise to a general reacion, rise of temperature, etc., as well as to a stick reaction, and is of diagnostic value, though neither is of decisive differential diagnostic value.

Williay J. Bether, M.D.

\section{New York Bovine Tuberculosis Inspection.}

Albany, N. Y., June 27,1908

To the Lditor:-I have read with interest the statements in TuE Jodinal of June 20, concerning bovine tubereulosis in Now York State. Feeling sure that you wish to present the facts correctly, I submit the following:

T'he Allds-Iansing bill when introduced provided for an additional appropriation of $\$ 200,000$. This was cut in the senate to $\$ 75,000$, which amount finally passed. This, together with the appropriation made in regular session of our legislature, puts about $\$ 130,000$ at the disposal of the commissioner of agriculture in connection with his work against contagious and infectious diseases of animals.

Our veterinarians visit herds where contagious or infectious diseases are supposed to exist. They always make a physical examination first. If tuberculosis is believed to exist, the owners of the herd are asked if they want the tuberculin test used and almost always they request it. We now have on file about sixty such requests. We attach great value to the tuberculin test, as it is the best means known for diagnosing tuberculosis. The physical test has some value and we are using it for what it is worth. It will reveal certain advanced cases of tuberculosis and certain bad cases of tuberculosis of the udder. Our experience has shown repeatedly that some cases of generalized tuberculosis, such as would undoubtedly result in the contamination of the meat of the animal, can not be recognized by physical examination alone, but, so far as we know, they are always found when the tuberculin test is applied.

The special point which I wish to make in connection with your statement is that we have not found the tuberculin test "unreliable as well as costly and cruel." You may be interested also to know that we are now killing such reacting animals as the owners do not wish to keep in quarantine. The killing is done under federal supervision, which permits the use of such meat as is found wholesome. This, we believe. removes the greatest objection to the use of tubercuin. It should not be overlooked also that our new amendment provides for larger payments to farmers for animals condemned on account of tuberculosis.

R. A. Pearson,

Commissioner, Department of Agriculture.

\section{Dr. Hoffa Not Born in America.}

Milwackee, Wis., Julv 5, 1908.

To the Editor:- Your Berlin correspondent, whom you introduced to your readers as a man of high standing, writes of the late Professor Hoffa: "He was closely related to Americans, as he was born in South America." Now, all the numerous biographin's of Hoffa I have read state that he was born in South Africa and was never in America until a few years ago. My criticism may scem trivial, but such statements, if allowed to stand, may reflect on the authenticity of other interesting things your correspondent is telling us.

Chester M. Echols, M.D.

\section{Medical Economics}

TIIS IUEARTMENT EMBBODINA IHE SCBIECTS OF ORGANIZA'LION, POSTGRADUATE WOIK, CONTRACT PRACTIC'E, INSCRANCE FEES, IEGISLATION, ETC.

\section{County Society Uses Local Newspapers.}

The Jefferson County (Texas) Medical Society has begun the publication in the newspapers of popular articles on medcine. The Beaumont Enterprise for Sunday, June 28, contains an excellent article, signed by the Jefferson County Medical Society, on "The Progress of Medical Science," wherein the development of medicine from earlier times to the present is briefly but interestingly summarized. Such articles published impersonally by a society for the benefit of the people of the county can not fail to be of great educational advantage.

\section{The Lay Press on Antivivisection.}

One of the most striking results of the recent session of the American Medical Association is the widespread and general comment of the better class of newspapers regarding the work and aims of the Association. It is equally significant that the feature of the session which attracted the most attention was the recommendation for a Council for the Defense of Vedical Research, in order to counteract the antivivisection agitation which has become noticeable in several states. It is particularly gratifying to note that the newspapers, without exception, condemmed the attempts to restrict seientific investigation by the limitation of animal experiments as unwise and unnecessary, and recognized that the regulation of such matters could safely be entrusted to the medical profession. One of the most interesting of these comments appeared in the Sioux City (Towa) Journal, in which the entire question is summarized with remarkable accuracy and clearness:

The aggressive stand in favor of vivisection taken by the American Medical Association at its Chicago meeting has renewed interest in an old debate. . . . The decision of the Association was that inasmuch as there is an organized campaign to promote sentiment against the practice a coun. ter campaign of education be undertaken in its behalf. It would seem that not much earnest effort along this line would be needed to cut the ground from under the antivivi. section propaganda. The sentiment against vivisection has been cultivated mainly by societies for the prevention of cruelty to animals. These societies do noble and useful work in protecting our animal friends from unnecessarily eruel treatment by brutal or thoughtless human beings. "In the mitter of vivisection, however, the advocates of humanity have taken the wrong tack and allowed their espousal of animal rights to supersede their recognition of human rights. Our whole civilization has moved on the theory that animal life must be sacrified to preserve human life. This principle is involved in the defense of vivisection, but the prosecution refuses to look at the real merits of the case. . . . In the battle against the bacilli the only way in which victory cant be won is by experiment. Shall the experiment be made with dogs and guinea-pigs, or with little children and their parents? Or shall there be no experiments, eren though there be certain knowledge that a suecessful experiment would save annually the lives of tens of thousands of human beings during all the generations to come? The antivirisectionists seem to think that doctors do their experimenting for their own amusement, and that they take a sort of fiendish satisfaction in the suffering that attends their work. As a matter of fact, the doctors are working for humanity in a much more practical way than the sentimentalists who are criticizing the inhumanity of vivisection. There may be cruelty in the connection with animal sacrifice, but it is safe to say there is very little avoidable cruelty. The newspapers that are proposing legislation against vivisection are proposing a very poor bargain. They propose in effect to trade a great deal of human life and happiness for a very little animal life and happiness. It is a proposal that can not withstand a campaign of education.

The Buffalo Nexs says editorially, speaking of the action of the Association:

'J'he reason is that so much unwisdom is uttered, such un- 